Int. J. Electrochem. Sci., 12 (2017) 9865 - 9881

\title{
Metal Complexes and Determination of Nalidixic Acid by Potentiometric and Conductometric Methods
}

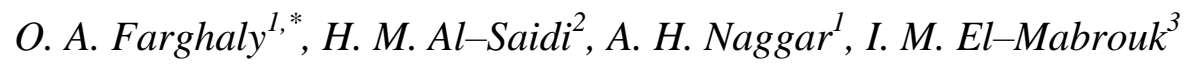 \\ ${ }^{1}$ Chemistry Department, Faculty of Science, Al-Azhar University, Assiut Branch, 71524, Assiut, \\ Egypt. \\ 2 Department of Chemistry, University College in Al-Jamoum, Umm Al-Qura University, 21955, \\ Makkah, Saudi Arabia \\ ${ }^{3}$ Chemistry Department, Faculty of Science, Sebha University, Sebha, Libya \\ E-mail: Othman15@yahoo.com
}

doi: $10.20964 / 2017.10 .29$

Received: 17 June 2017 / Accepted: 30 July 2017 / Published: 12 September 2017

Ten metal ions viz, Fe(III), Cr(III), La(II), Sn(II), Co(II), Ba(II), Pd(II), Ti(II), Sr(II) and Zr(IV), were selected to elucidate their interaction with nalidixic acid (NA) using potentiometric and conductometric methods. The ligand ionization and the complexes stability constants have been obtained at $25 \pm 1.0{ }^{\circ} \mathrm{C}$ and $0.01 \mathrm{M}$ ionic strength of $\mathrm{NaCl}$ in $25 \%(\mathrm{v} / \mathrm{v})$ aqueous-ethanol solution. Complexes of 1:1, 1:2 and/or 1:3 metals to ligand ratios were formed depending on the nature of the ligand or metal ions. As well as, the stoichiometry of complexes confirmed by the conductometric method. Also simple, precise, rapid and low-cost potentiometric and conductometric methods for NA determination and tablets are proposed. NA present in tablets containing known quantity of drug was potentiometrically titrated by $0.1 \mathrm{M}$ of $\mathrm{NaOH}$ using a combined glass $\mathrm{pH}$ electrode. The detection limit was $0.19 \mathrm{mg} \mathrm{L}^{-1}$. The calibration graph was found to be linear in the range of $0.23-2.55 \mathrm{mg} \mathrm{L}^{-1}$. The correlation coefficient ( $r$ ) was calculated to be 0.9952 . The standard deviation (SD) was < 1.0. No interferences were observed in the presence of common components of the tablets. The percentage recoveries of NA in tablet dosage formulations by potentiometric and conductometric methods were (95.8-98.68) \%, with standard deviations (SD) were within $(0.18-0.4)(\mathrm{n}=5)$.

Keywords: Nalidixic acid, metal complexes, potentiometric and conductometric determination, tablets.

\section{$\underline{\text { FULL TEXT }}$}

(C) 2017 The Authors. Published by ESG (www.electrochemsci.org). This article is an open access article distributed under the terms and conditions of the Creative Commons Attribution license (http://creativecommons.org/licenses/by/4.0/). 